\title{
Ground Source Heat Pump with Passive Heat Compensation Tower SONG Yanli ${ }^{1, a}$, Du Tao ${ }^{1, b}$, Ren Dong ${ }^{1, c}$ \\ ${ }^{1}$ SEP Key Laboratory of Eco-Industry, Northeastern University, Shenyang \\ a syjz_song@163.com, b dut@smm.neu.edu.cn, c1525108784@qq.com
}

\section{Keywords: Ground source heat pump, Heat loss, The Passive Heat Compensation Tower} Abstract. The collation and analysis of the existing problems of ground source heat pump system and the existing solutions, based on the research and development of a new patch of ground source heat pump tower, through the experiment, obtained in the air temperature is $27.1^{\circ} \mathrm{C}$, the wet bulb temperature is $19.8{ }^{\circ} \mathrm{C}$, the dew point temperature of $15.5^{\circ} \mathrm{C}$, relative humidity is $46 \%$, supplement run a tower in the ground source heat pump water temperature rise after passive, $2.43{ }^{\circ} \mathrm{C}$, after the water temperature gradually declines, in ninth after the operation, the temperature rise of $0.15^{\circ} \mathrm{C}$, tenth times after the operation, the temperature rise of $0.1^{\circ} \mathrm{C}$, up to the tower using passive soil heat is feasible.

\section{Introduction}

Ground source heat pump system is used to input a small amount of high (e.g., electricity), from the shallow ground to heat, low heat energy in the groundwater or surface water (soil) in low heat to heat pump air conditioning system of high heat transfer [1].

The ground source heat pump system, the winter without burning process, no pollutants, summer floating water loss reduces the cooling tower, slows down the urban heat island effect, has very significant economic and social benefits. Maintenance cost is low, not with the installation of outdoor equipment, work stability.

When soil source heat pump system in an average annual don`t equilibrium region appear cold and hot load put on the summer to soil accumulation of heat and heat from the soil in winter, so for a long time for the accumulation of heat and heat quantity imbalance will exceed the soil's ability to spread heat itself, formed the so-called cold heat accumulation, continuously deviates from the initial temperature, soil temperature of soil thermal imbalance [2]. For a soil source heat pump system from 1994 to 2004 to monitor the running status results show that the soil heat exchanger area up $11{ }^{\circ} \mathrm{C}$ temperature. Usually, soil temperature rise (reduce) of preparing $1{ }^{\circ} \mathrm{C}$ can make the same amount of cold energy consumption increase by $3-4 \%$ [3].

With the extension of ground source heat pump, its running time is longer and longer, and the problem of soil thermal imbalance is more and more serious. Moreover, the existing solutions have their limitations. Therefore, it is very important to explore the application of the ground source heat pump and the problems exposed, to explore the application of more stable, energy-saving and environmental protection to solve the problem of thermal imbalance in cold regions. This paper developed a new way of heat - source heat pump passive fill tower. This added tower via air and water heat and moisture exchange so as to increase the water temperature, the heat back to the underground, improve the energy flow density of reinforcing heat, to complement the heat to the underground soil with the least energy consumption.

Although the outdoor temperature is low in winter in the northern part of the country, the outdoor air temperature is higher in summer and in the transitional season. The complement of passive heat pump hot tower, can make full use of heat energy in the air. According to the principle of heat and moisture exchange, the heat exchange between the lower ground water and the higher temperature air is used to heat up the underground water, so as to achieve the purpose of heating the underground soil. 


\section{Existing Solutions}

Thermal imbalance of soil is caused by many factors, analysis its reason mainly is: on the one hand, is one of the characteristics of shallow geothermal energy. In northern cold region of soil of ground source heat pump to heat balance, the current solution is mainly divided into two categories[4-6]:

(1) The optimization of the underground heat exchanger structure, enlarge the heat exchanger and the heat transfer area of the soil, such as the increasing number of buried pipe, buried pipe length and increasing the spacing between ground control.

(2) The use of auxiliary energy solar collector, etc.

(3) Increase the auxiliary heating boilers

The shortcoming of traditional heating method is generally can make up for heat flow density is low, at the same time there are other energy consumption is larger, covers an area of large, disadvantage in aspects of heat loss is bigger. In order to solve the existing heating technology could fill heat flow density low problem, this article designs a kind of passive hot towers. The so-called passive is the active use of the high grade energy, but the use of passive solar wind could air such as low grade energy, to achieve the purpose of heating. The heat compensation method for figer 1 .
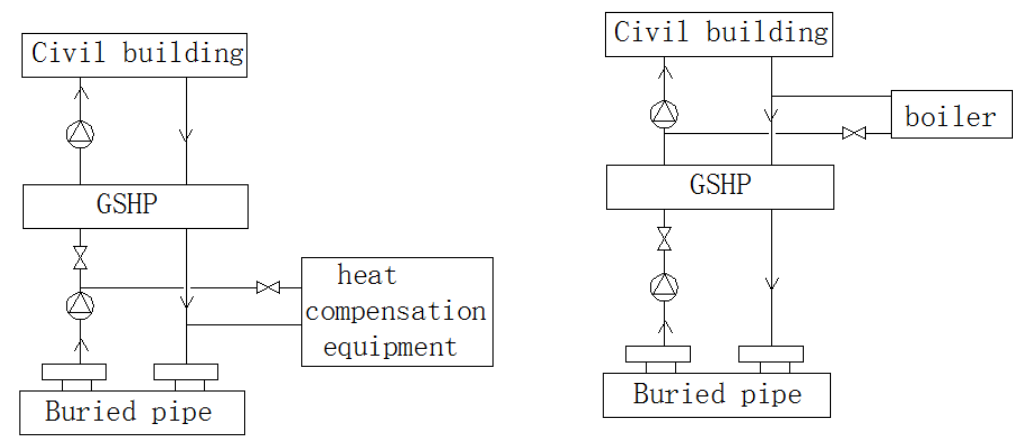

Fig1 The heat compensation method

\section{A New Type of Thermal Model}

This paper developed a new type of fill - ground source heat pump heat model passive hot towers. This heating tower through the air and the water heat exchange water temperature rise, will be returning to the underground heat, can improve the filling heat flow density, to try to small for the underground soil heating energy consumption to achieve. Thermal performance test to determine the air through the design experiment, and the feasibility of water after heat exchange water temperature increases.

Ground source heat pump passive heating tower, can make full use of the heat energy in the air. The unit according to the principle of heat exchange, the use of low temperature of groundwater with high temperature air heat exchange, the groundwater, so as to achieve the aim of for the underground soil heating.

Passive heating tower is composed of the following sections, including fan, water spray, such as enthalpy humidifying paragraphs, heat exchange, air outlet section, filter section water, warm water backwater section, overflow section, to increase the overflow section.

Fan section is composed of fan motor, fan, main effect is to speed up the air flow, promote the heat exchange between air and water, and make heat exchange more fully. Such as enthalpy humidifying section is composed of high pressure water mist water supply pipe, through the high pressure water mist flow pipe such as enthalpy of air humidification, is advantageous for the next heat exchange between air and water. Spray section is composed of cold water supply, groundwater by water pump, even shoot by the cold water pipes, in the next period of air and water to heat exchange. Heat exchange section is composed of heat exchange packing, air and water in the hot wet exchange of heat 
exchange on the packing, the air temperature is reduced, the water temperature. Air outlet section is composed of air outlet grille, the air in the heat exchange and water to heat exchange, fill out here hot towers, to prevent the tower air pressure is too high, influence the entrance into the air. Filtering section is composed of filter and filter holder, filtered water here, filter the impurities in water, prevent impurities of pipeline and the pollution of groundwater. Warm water backwater section is composed of filling water pipe as well as the warm water return pipe, groundwater and air after heat exchange, temperature, through the warm water return pipe to return to the ground, to hot up in underground.

\section{Main Experimental Results}

Groups of laboratory experiment condition parameters shown in the following table. Adjust the water temperature, when the water temperature of $11.5^{\circ} \mathrm{C}$, started the passive fill hot towers, each a heat exchange circulating, measuring the inlet and outlet temperature of the water. In order to guarantee the accuracy, respectively in two birdbath choose 12 different measuring point, 12 measured temperature averaging get a set of data. The average exit temperature take 12 groups of data, computing. As the number of heat exchange more, higher water temperature as, lower temperature range.

Tab 1 Experiment Parameter

\begin{tabular}{cccccc}
\hline $\begin{array}{c}\text { Air } \\
\text { temperature } /{ }^{\circ} \mathrm{C}\end{array}$ & $\begin{array}{c}\text { Web bulb } \\
\text { temperature } /{ }^{\circ} \mathrm{C}\end{array}$ & $\begin{array}{c}\text { Dew point } \\
\text { temperature } /{ }^{\circ} \mathrm{C}\end{array}$ & $\begin{array}{c}\text { Relative } \\
\text { humidity } / \%\end{array}$ & $\begin{array}{c}\text { Wind } \\
\text { speed m/s }\end{array}$ & $\begin{array}{c}\text { Rate of } \\
\text { flow L/h }\end{array}$ \\
\hline 26.9 & 19.8 & 15.5 & 46 & 3.1 & 310 \\
\hline
\end{tabular}

Experiments conducted a series of 10 , the initial temperature of $13.5{ }^{\circ} \mathrm{C}$, the temperature difference between each group, group of 10 temperature $20.5{ }^{\circ} \mathrm{C}$, temperature difference before and after the operation has been reduced to $0.1{ }^{\circ} \mathrm{C}$, considering the error of measurement, the approximate think temperature equilibrium. Can be seen from the record the water temperature, initial water temperature is $11.5{ }^{\circ} \mathrm{C}$, after 10 times after the operation, high water temperature zhu and steady at $20.4{ }^{\circ} \mathrm{C}$.

Tab 2 Experimental data calculation result table

\begin{tabular}{|c|c|c|c|c|}
\hline Item & Designation & Sign & Unit & Calculated value \\
\hline \multirow{9}{*}{$\begin{array}{c}\text { Air side } \\
\text { parameter } \\
\text { calculation }\end{array}$} & $\begin{array}{l}\text { The local atmospheric pressure } \\
\text { table }\end{array}$ & $\mathrm{Pa}$ & $\mathrm{KPa}$ & 100.7 \\
\hline & Saturated vapor pressure & $\mathrm{Ps}_{\mathrm{s}}$ & $\mathrm{Pa}$ & 1800 \\
\hline & Water vapor partial pressure & $\mathrm{Pq}$ & $\mathrm{Pa}$ & 1188.78 \\
\hline & Moisture content & $\mathrm{d}$ & $\mathrm{kg} / \mathrm{kg}$ dry air & $7.43 \times 10^{-3}$ \\
\hline & Initial state enthalpy & i1 & $\mathrm{kJ} / \mathrm{kg}$ dry air & 44.88 \\
\hline & Final state of enthalpy & $\mathrm{i} 2$ & $\mathrm{~kJ} / \mathrm{kg}$ dry air & 43.31 \\
\hline & The wind speed & $\mathrm{V}$ & $\mathrm{m} / \mathrm{s}$ & 3.1 \\
\hline & The air volume & $\mathrm{Ga}$ & $\mathrm{kg} / \mathrm{s}$ & 0.25 \\
\hline & Air side heat loss & Q1 & $\mathrm{kW}$ & 0.39 \\
\hline \multirow{3}{*}{$\begin{array}{l}\text { Water side } \\
\text { parameter } \\
\text { calculation }\end{array}$} & Amount of water & Gw & $\mathrm{kg} / \mathrm{s}$ & 0.081 \\
\hline & $\begin{array}{c}\text { Water heating equilibrium } \\
\text { temperature }\end{array}$ & tph & ${ }^{\circ} \mathrm{C}$ & 20.4 \\
\hline & Water side heat gain & Q2 & $\mathrm{kW}$ & 0.41 \\
\hline \multirow[b]{2}{*}{ Deviation } & Air side heat balance deviation & $\varepsilon_{a}$ & $\%$ & 5.1 \\
\hline & $\begin{array}{c}\text { Water side heat balance } \\
\text { deviation }\end{array}$ & $\varepsilon_{\mathrm{w}}$ & $\%$ & 4.8 \\
\hline
\end{tabular}


From the experimental data, the experiment began, in the first through the hot water tower, $1-3{ }^{\circ} \mathrm{C}$ temperature will rise, as the stability of heat exchange, also came to balance, water temperature no longer rises.

In the experiment the first run, by the water side heat gain knowledge passive heating power is 0.82 $\mathrm{kW}, 0.15 \mathrm{~kW}$ water pump power, the fan power is $0.12 \mathrm{~kW}$, the heat from the air power is $0.55 \mathrm{~kW}$, accounting for $67.1 \%$ of the passive heating power tower. Therefore, compared with the resistance heater to heat the water to heat up, passive heating energy saving potential is great.

\section{Conclusions}

1. The deviation of air side epsilon $\mathrm{a}=5.1 \%$, deviation of water side for epsilon $\mathrm{w}=4.8 \%$. Calculate the heat balance deviation epsilon a (w) of $10 \%$ or less, the results available; A second set of experiments, the lateral deviation on the air epsilon $\mathrm{a}=5.1 \%$, deviation of water side for epsilon $\mathrm{w}=$ $4.8 \%$. Calculate the heat balance deviation epsilon a (w) $10 \%$ or less, the experimental results are available.

2. The air temperature is $27.1{ }^{\circ} \mathrm{C}$, wet bulb temperature is $19.8{ }^{\circ} \mathrm{C}$, the dew point temperature is $15.5^{\circ} \mathrm{C}$, relative humidity was $46 \%$, in the ground source heat pump passive hot towers run once, the water temperature increased by $2.43{ }^{\circ} \mathrm{C}$, the water temperature rise after gradually reduce, in the ninth after the operation, the water temperature increased by $0.15{ }^{\circ} \mathrm{C}, 10$ times after the operation, the water temperature rise by $0.1{ }^{\circ} \mathrm{C}$, and considering the change of the indoor environment and measurement error, etc., can maintain the water balance. Therefore, the use of passive thermal tower for the underground soil hot tonic is feasible.

\section{Acknowledgements}

This work was financially supported by the Natural Science Foundation of China (Grant Nos. 51474067 and 51406029)

\section{References}

[1]Wu Tong, Liu Yuying, Dong Zhe, the status quo of research and application of ground source heat pump [J]. Journal of refrigeration technology, 2014, 71:71-75.

[2]Zhang Susu. Unbalanced regional soil source heat pump hot and cold load thermal imbalance of soil research [D]. Yangzhou university, 2014.

[3]Fan Longhua, wang yong. Heat balance of ground heat exchanger in soil source heat pump system problems and solutions [J]. Journal of heilongjiang metallurgy, 2011,01:44-45.

[4]Wang K, Sun F Z, Zhao Y B, et al. Experimental research of the guiding channels effect on the thermal performance of wet cooling towers subjected to crosswinds - Air guiding effect on cooling tower[J]. Applied Thermal Engineering, 2010, 30, 533-538.

[5]You T, Wang B L, Wu W, et al. A new solution for underground thermal imbalance of ground-coupled heat pump systems in cold regions: Heat compensation unit with thermosiphon[J]. Applied Thermal Engineering, 2014, 64, 283-292.

[6]Tan K X, Deng S M. A numerical analysis of heat and mass transfer inside a reversibly used water cooling tower[J]. Building and Environment, 2003, 38, 91-97.

[7] Pascal S, Dominique M. Simplified model for indirect-contact evaporative cooling-tower behavior[J]. Applied Energy, 2004, 78, 433-45. 